\title{
Micropollutant Removal from Water by Membrane and Advanced Oxidation Processes-A Review
}

\author{
Larissa L. S. Silva, Carolina G. Moreira, Bianca A. Curzio, Fabiana V. da Fonseca \\ Chemistry School, Rio de Janeiro Federal University, Rio de Janeiro, Brazil \\ Email: larissaloureiross@hotmail.com
}

How to cite this paper: Silva, L.L.S., Moreira, C.G., Curzio, B.A. and da Fonseca, F.V. (2017) Micropollutant Removal from Water by Membrane and Advanced Oxidation Processes-A Review. Journal of Water Resource and Protection, 9, 411-431. https://doi.org/10.4236/jwarp.2017.95027

Received: August 15, 2016

Accepted: April 14, 2017

Published: April 17, 2017

Copyright ( $) 2017$ by authors and Scientific Research Publishing Inc. This work is licensed under the Creative Commons Attribution International License (CC BY 4.0).

http://creativecommons.org/licenses/by/4.0/

(c) (i) Open Access

\begin{abstract}
Micropollutants are defined as contaminants found in trace concentrations in water bodies that are persistent and bioactive, meaning they are not completely biodegradable and cannot be removed by conventional water treatment methods. Because of these aspects, their detection and removal pose a challenge to the scientific community. Among them are endocrine disruptors, drugs, agricultural chemicals, personal grooming products, industrial additives and others. These micropollutants are the cause for global concern, because their presence in water supply systems is suspected of causing health problems in humans and animals. To develop efficient techniques to remove them, it is fundamental to understand their physico-chemical properties and the available treatment types and conditions. Membrane separation processes (MSPs) and advanced oxidation processes (AOPs) are the focus of this literature review, as potential treatment methods to remove micropollutants. The former process stands out for high rejection rates (above 90\%) of various micropollutants, but it generates a concentrated secondary waste stream. In turn, the latter process can remove micropollutants without generating secondary wastes, and can also be applied and combined with other treatment methods.
\end{abstract}

\section{Keywords}

Micropollutants, MSP, AOP

\section{Introduction}

In recent decades, the presence of many substances in water bodies that can harm human and animal health has caused the growing concern. Among these substances are emerging micropollutants, present in both industrial and household wastewater in vestigial quantities, with concentrations ranging in scale from 
$\mu \mathrm{g} \cdot \mathrm{L}^{-1}$ and $\mathrm{ng} \cdot \mathrm{L}^{-1}$. Some of these compounds known as Endocrine Disrupters (ED) are considered exogenous agents that interfere with the synthesis, secretion, transport, binding and action or elimination of natural hormones in the body which are responsible for maintenance, reproduction, development, and/or behavior organisms [1]. Among the sources of these substances are pharmaceutical products, personal grooming products, steroid hormones, industrial chemicals, pesticides and many other substances.

Many researchers have investigated the effect of these substances in water bodies, observing harmful effects on humans and animals, such as endocrine system anomalies, cancer, reduction of sperm quantity and endometriosis, among others [2] [3]. Furthermore, micropollutants can act synergistically with other substances, aggravating the negative effects [4].

Strategic programs for the development of detection protocols and regulatory laws that include the ED as the imminent risk to the health of animals and humans have been proposed, including "Two-tier Endocrine Disruptor Screening" (EDSP-USEPA), "Strategic Programs on Endocrine Disruptors" (SPEED_Japan Environment Agency), and "21 Joint Working Group on Endocrine Disrupters Testing and Assessment” (EDTA-OECD) [5].

The presence of micropollutants in aquatic environments has also been associated with the development of resistance to antibiotics by microorganisms. However, because of their low concentrations and wide diversity of types, the methods to detect and analyze micropollutants are not always precise, posing a challenge to wastewater treatment facilities [6] [7]. Figure 1 shows the route of environmental contamination by micropollutants. Sorption in sediments of rivers,

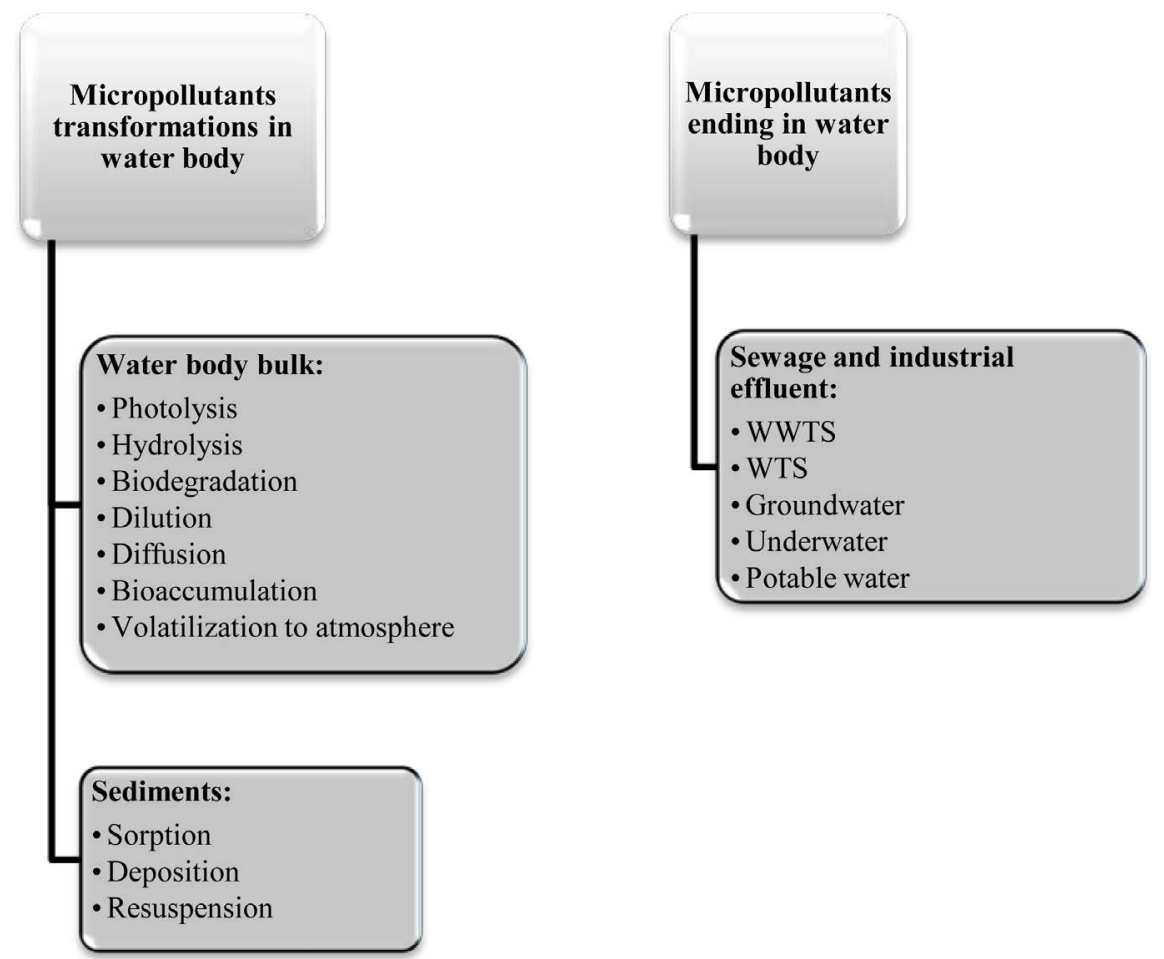

Figure 1. Environmental contamination route by micropollutants. 
bioaccumulation and biomagnification can be considered; there are many works that relate these phenomenon [8] [9]. Despite the difficulty of degradation, several reactions can occur in the natural environment, such as photolysis (breakdown of substances by presence of sunlight), biodegradation (the presence of organic wastes favors proliferation of microorganisms) and hydrolysis (highly polar molecules). These reactions can generate active substances or biologically inactive, e.g. the natural estrogens are excreted by human body in idle and when incorporated into the environment so go to form active, may cause deleterious effects to biota around [2] [8]. Another phenomenon that must also be considered is the volatilization compound to the atmosphere.

The technologies used by water treatment stations (WTS) and wastewater treatment stations (WWTS) are generally not effective in removing these micropollutants, because many are hard to separate and/or resistant to degradation. Compounding this problem, no monitoring is conducted for the majority of these contaminants, which are typically only present in trace levels [10].

Therefore, it is necessary to develop new technologies for removing micropollutants, to prevent their bioaccumulation and the consequent aggravation of the deleterious effects on human and animal health. Recently, membrane separation processes (MSP) and advanced oxidation processes (AOP) are becoming consolidated as effective technologies to remove micropollutants.

The application of MSP, with nanofiltration (NF) and reverse osmosis (RO) membranes is growing among tertiary treatment methods, especially for use by wastewater/sewage treatment plants. The high purity of the treated water is due to the ability of these membranes to separate salts (RO) and organic compounds with low molecular weight (NF).

The AOP, especially those involving ultraviolet radiation, hydrogen peroxide and/or ozone, have been widely studied and found to be highly efficient in removing micropollutants. The main advantage of this process is the possibility of complete mineralization of the organic matter without generating secondary wastes and sludge.

\section{Membrane Separation Process}

Membranes are known as selective barriers that separate two phases and restrict the transport of various chemicals [11]. The most important property of membranes is their ability to control the rate of permeation of different species [12].

The separation mechanism depends on the type of membrane, the presence of pores and morphology or structure. There are three forms of separation: size exclusion (MF and UF), rejection by difference in solubility and diffusivity (RO) and separation by charge difference between species (Electrodialysis membranes). Especially for NF membranes, occur three mechanisms, because these membranes have dense and porous parts, as well as charges on their surface [13].

According to Baker [12], the mechanism of transport through RO membranes is called the solution-diffusion model. In this model, solutes permeate the membrane by dissolving in the membrane material and diffusing down a concentra- 
tion gradient. Separation occurs because of the difference in solubility and mobility of different solutes in the membrane.

The removal of micropollutants by MSP has been amply investigated, especially RO and NF membranes, which can retain dissolved salts and solutes, being adequate for the majority of micropollutants that have molecular weight in the range of $200-400 \mathrm{Da}$ [14] [15]. When comparing the removal efficiency of RO and NF membranes, the former can retain a larger number of micropollutants, because their pores are smaller [14]. However, NF membranes have other specific features that favor their use, such as retention efficiency very near that of RO membranes, the possibility of working with greater flows and/or lower pressures, lower fouling rates and lower cost [16] [17] [18].

Table 1 lists the publications that have assessed the removal of micropollutants by MSP in different aquatic matrixes.

Factors such as membrane properties, physico-chemical characteristics of the substances targeted for removal, transport mechanism and matrix effect should be taken into consideration when evaluating MSP [14] [19].

The membrane's selectivity can be related to several mechanisms: size exclusion, electrostatic repulsion, adsorption, diffusion, solute-solute interaction and fouling. Simon et al. [20] assessed the adsorption of ibuprofen by NF and RO membranes and found that this phenomenon is directly linked to the electrostatic repulsion between the pollutant and membrane and the solution's $\mathrm{pH}$. In other words, reducing the $\mathrm{pH}$ to values below the $\mathrm{pKa}$ (acid dissociation constant) of ibuprofen weakens the electrostatic repulsion, because the membrane becomes positively charged, facilitating the adsorption of ibuprofen inside the membrane, which has a negative surface charge. Shanmugana than et al. [21] found higher removal rates (97\%) of ionic compounds than nonionic ones (82\%) by NF and RO membranes. Therefore, the diffusion phenomenon degrades the membrane's efficiency in removing substances by adsorption.

According to Sahar et al. [22], the drug diclofenac was removed by RO membranes (negative surface charge) at rates above $95 \%$, due to the electrostatic repulsion between the membrane and this micropollutant. In another study, the same effect was observed when analyzing diclofenac and other drugs as well as personal grooming products whose charges are negative when in solution, such as ibuprofen, glimepiride, naxoprene and sulfametoxazole [19]. The removal efficiency diminished considerably for micropollutants having neutral or positive charges. For example, the removal was near $100 \%$ fornaxoprene, versus $20 \%$ for acetaminophen (neutral) and 60\% for athenolol (positive) [23].

In the case of adsorption, Gur-Reznik et al. [24] found that for some substances with low hydrophobicity and high $\mathrm{pKa}$, such as carbamazepine and diatrizoate, the adsorption by NF and RO membranes is negligible, so the effective mechanism in this case is size exclusion. Linares et al. [25] confirmed this possibility, indicating that hydrophilic compounds with neutral charges are only weakly adsorbed when fouling is not present. Cartagena et al. [17] reported the same phenomenon, confirming that in this case the higher the value of LogKow (octanol-water partition coefficient), the better the removal rates are. 
Table 1. Micropollutant removal from different matrixes by distinct membrane separation processes.

\begin{tabular}{|c|c|c|c|c|c|}
\hline Reference & Matrix & Membrane type & Operation conditions & Micropollutants & Removal \\
\hline$[15]$ & $\begin{array}{c}\text { Secondary } \\
\text { treatment effluent }\end{array}$ & $\begin{array}{c}\text { MF/UF } \\
\text { ZeeWeed1000 } \\
\text { (PVDF) }\end{array}$ & $\begin{array}{l}\text { flow } 1.3 \mathrm{~m}^{3} \cdot \mathrm{h}^{-1}, 75 \%-80 \% \\
\text { recovery, } 0.4-0.6 \mathrm{bar}\end{array}$ & $\begin{array}{l}\text { chloramphenicol, } \\
\text { trimethoprim, bezafibrate, } \\
\text { clofibric acid, gemfibrozil, } \\
\text { diclofenac, indomethacine, } \\
\text { ketoprofen, etc. }\end{array}$ & $50-90$ \\
\hline$[17]$ & $\begin{array}{l}\text { MBR (FS) effluent// } \\
\text { MBR (HF) effluent }\end{array}$ & $\begin{array}{l}\text { RO, BW30-4040 } \\
\text { (polyamide) } \\
\text { NF, NF90-4040 } \\
\text { (polyamide) } \\
\text { MBR }\end{array}$ & $\begin{array}{l}15 \% \text { recovery, } 7.5 \mathrm{bar} \text {, } \\
\text { permeate flow } 7.2 \mathrm{~m}^{3} \cdot \mathrm{h}^{-1} \\
15 \% \text { recovery, } 5.5 \mathrm{bar}, \\
\text { permeate flow } 7.2 \mathrm{~m}^{3} \cdot \mathrm{h}^{-1} \\
\text { hollow fiber }\end{array}$ & $\begin{array}{l}\text { acetaminophen, ibuprofen, } \\
\text { caffeine, nicotine, } \\
\text { carbamazepine, diclofenac, } \\
\text { triclosan, 4-octylphenol, } \\
\text { 4-t-octylphenol, bisphenol A }\end{array}$ & $50-100$ \\
\hline$[18]$ & $\begin{array}{l}\text { Second treatment } \\
\text { effluent, } \\
\text { ultrapure water }\end{array}$ & $\begin{array}{c}\text { NF, NFX } \\
\text { (polyamine) }\end{array}$ & $\begin{array}{l}\text { cross-flow, flat sheet, } \\
75 \% \text { recovery, } 2 \text { - } 10 \text { bar }\end{array}$ & $\begin{array}{l}\text { norfloxacin, } \\
\text { ofloxacina, } \\
\text { azithromycin, } \\
\text { roxithromycin }\end{array}$ & $>98$ \\
\hline [19] & WWTP effluent & $\begin{array}{c}\text { NF, NE40, } \\
\text { NE70 e NE90 } \\
\text { (polyamide) } \\
\text { MBR } \\
\text { polyvinylidene }\end{array}$ & $\begin{array}{c}3.5 \mathrm{bar}, \text { retention flow } \\
0.030 \mathrm{~m}^{3} \cdot \mathrm{h}^{-1}, 6-10.9 \mu \mathrm{m} \cdot \mathrm{s}^{-1}\end{array}$ & $\begin{array}{l}\text { acetaminophen, atenolol, } \\
\text { carbamazepine, clopidogrel, } \\
\text { diclofenac, dilantin, } \\
\text { ibuprofen, iopromide, } \\
\text { glimepiride, naxopren, } \\
\text { sulfamethoxazole }\end{array}$ & $15-98$ \\
\hline [20] & $\begin{array}{c}\text { Synthetic } \\
\text { water/ } \mathrm{NaOCl}\end{array}$ & $\begin{array}{c}\text { NF, TFC-SR2, } \\
\text { NF-270, NF90 } \\
\text { RO, BW30 }\end{array}$ & $\begin{array}{c}\text { permeate flux } \\
0.054 \mathrm{~m}^{3} \cdot \mathrm{m}^{-2} \cdot \mathrm{h}^{-1} ; \mathrm{pH} 4-10\end{array}$ & $\begin{array}{l}\text { sulfamethoxazole, } \\
\text { carbamazepine, ibuprofen }\end{array}$ & $5-100$ \\
\hline [21] & $\begin{array}{l}\text { Second } \\
\text { treatment } \\
\text { effluent }\end{array}$ & $\begin{array}{c}\text { NF, NTR 729HF } \\
\text { (polyvinylalcohol/polyamide) }\end{array}$ & $\begin{array}{l}\text { flat sheet, permeate flux } \\
0.0485 \mathrm{~m}^{3} \cdot \mathrm{m}^{-2} \cdot \mathrm{h}^{-1}, 4 \text { bar }\end{array}$ & $\begin{array}{l}\text { atenolol, caffeine, } \\
\text { carbamazepine, diclofenac, } \\
\text { gemfibrozil, naproxen, } \\
\text { sulfamethoxazole, } \\
\text { triclosan, trimethoprim }\end{array}$ & 99 \\
\hline$[22]$ & $\begin{array}{l}\text { Primary } \\
\text { treatment effluent }\end{array}$ & $\begin{array}{l}\text { MBR, UF, ZeeWeed-1000 e } \\
\text { ZeeWeed-500 }\end{array}$ & $\begin{array}{c}80 \%-90 \% \text { recovery, } \\
\text { flow } 22-45 \mathrm{~m}^{3} \cdot \mathrm{h}^{-1} \\
8.7-12 \mathrm{bar}\end{array}$ & $\begin{array}{l}\text { Salycilic acid, ibupropheno, } \\
\text { bisphenol A, diclofenac, } \\
\text { cholesterol, sulfamethoxazole, } \\
\text { sulfamethazine, } \\
\text { trimethoprim, } \\
\text { erythromycin, } \\
\text { clarithromycina, } \\
\text { roxithromycin }\end{array}$ & $93-99$ \\
\hline [23] & $\begin{array}{c}\text { Primary treatment } \\
\text { effluent }\end{array}$ & RO, TR70-4021 (polyamide) & 10 bar, flow $0.18 \mathrm{~m}^{3} \cdot \mathrm{h}^{-1}$ & $\begin{array}{l}\text { codeine, carbamazepine, } \\
\text { diazepam, ranitidine, } \\
\text { azithromycin, } \\
\text { clarithromycin, erithromycin, } \\
\text { sulfamethoxazole, etc. }\end{array}$ & 99 \\
\hline$[24]$ & MBR effluent & RO, XLE, BW30 e SW3O & $\begin{array}{c}5 \text { bar } \\
7-55 \text { bar, concentrateflow } \\
0.18-0.24 \mathrm{~m}^{3} \cdot \mathrm{h}^{-1} \\
\text { permeateflow } \\
0.00004-0.0001 \mathrm{~m}^{3} \cdot \mathrm{h}^{-1}\end{array}$ & carbamazepine e diatrizoate & $41-100$ \\
\hline
\end{tabular}




\section{Continued}

\begin{tabular}{|c|c|c|c|c|c|}
\hline [25] & $\begin{array}{c}\text { Secondary treatment } \\
\text { effluent }\end{array}$ & $\begin{array}{c}\text { FO } \\
\text { (poly methyl methacrylate) }\end{array}$ & $\begin{array}{l}\text { flat sheet, } 15 \text { bar, permeate } \\
\text { flow } 0.000096 \mathrm{~m}^{3} \cdot \mathrm{h}^{-1} \text {, } \\
\text { concentrate flow } \\
0.0048 \mathrm{~m}^{3} \cdot \mathrm{h}^{-1} \text {, flux } 0.007 \\
\mathrm{~m}^{3} \cdot \mathrm{m}^{-2} \cdot \mathrm{h}^{-1}, 2 \% \text { recovery } \\
\text { flat sheet, recirculation } \\
\text { flow } 0.003 \mathrm{~m}^{3} \cdot \mathrm{h}^{-1}\end{array}$ & $\begin{array}{l}\text { 1,4-dioxin, acetaminophen, } \\
\text { metronidazole, phenazone, } \\
\text { caffeine, bisphenol A, } \\
\text { carbamazepine, } \\
\text { 17a-ethinylestradiol, ibuprofen, } \\
\text { naxopren, fenoprofen, } \\
\text { gemfibrozil, ketoprofen }\end{array}$ & $40-100$ \\
\hline [26] & WWTP effluent & $\begin{array}{c}\text { RO, RE8040-FL (polyamide) } \\
\text { UF, P75R (PVDF) }\end{array}$ & $\begin{array}{l}\text { 72.6\% recovery, } \\
\text { permeate flow } 3.42 \mathrm{~m}^{3} \cdot \mathrm{h}^{-1} \\
\text { permeate flow } 9.46 \mathrm{~m}^{3} \cdot \mathrm{h}^{-1}\end{array}$ & $\begin{array}{l}\text { atenolol, carbamazepine, } \\
\text { caffeine, diclofenac, dilatin, } \\
\text { florfenicol, sulfamethoxazole }\end{array}$ & $19-99$ \\
\hline [27] & Synthetic water & & $\begin{array}{l}\text { NF, NF-200 e NF-90 } \\
\text { (polyamide), flat sheet, } 2 \\
\text { and } 8 \% \text { recovery, } 2.76 \text { and } \\
4.82 \mathrm{bar} \text {, permeate fluxes } \\
0.00018-0.0012 \mathrm{~m}^{3} \cdot \mathrm{m}^{-2} \cdot \mathrm{h}^{-1}\end{array}$ & $\begin{array}{l}\text { caffeine, sulfamethoxazole, } \\
\text { acetaminophen, carbamazepine, } \\
\text { naxopren, ibuprofen, } \\
\text { metronidazole, estrone, } \\
\text { 17ß-estradiol, bisphenol A, } \\
\text { nonylphenol, atrazine }\end{array}$ & $21-99$ \\
\hline [28] & $\begin{array}{c}\text { Secondary } \\
\text { treatment effluent }\end{array}$ & $\begin{array}{l}\text { RO, HR-4040 e LE-4040 } \\
\text { NF, NF270-4040 }\end{array}$ & $\begin{array}{c}73 \% \text { recovery, permeate } \\
\text { flow } 50 \mathrm{~m}^{3} \cdot \mathrm{h}^{-1} \\
86 \% \text { recovery, permeate } \\
\text { flux } 68.33 \mathrm{~m}^{3} \cdot \mathrm{h}^{-1}, \\
\text { inlet flow } 79.58 \mathrm{~m}^{3} \cdot \mathrm{h}^{-1} \\
- \\
12 \text { - } 15 \% \text { recovery, } \\
\text { permeate flow } \\
0.40-0.46 \mathrm{~m}^{3} \cdot \mathrm{h}^{-1}, 5-11.8 \mathrm{bar}\end{array}$ & $\begin{array}{l}\text { EDTA, nonylphenol, } \\
\text { estrone, 17 } \beta \text {-estraiol, } \\
\text { 17a-ethinylestradiol, } \\
\text { tributyltin, naphthalene, } \\
\text { ibuprofen, ofloxacin, } \\
\text { oxytretacyc, erythromycin, } \\
\text { propanolol, fluoxetine, etc. }\end{array}$ & $15-99$ \\
\hline & & MBR & hollow fiber & & \\
\hline [29] & $\begin{array}{l}\text { Activated Sludge } \\
\text { effluent }\end{array}$ & $\begin{array}{l}\text { RO, ULP-4040 (polyamide) } \\
\text { MF, HF-66-43-PM500 }\end{array}$ & $\begin{array}{l}65 \% \text { recovery, permeate } \\
\text { flux } 0.034 \mathrm{~m}^{3} \cdot \mathrm{m}^{-2} \cdot \mathrm{h}^{-1} \\
\text { hollow fiber, permeate } \\
\text { flux } 0.323 \mathrm{~m}^{3} \cdot \mathrm{m}^{-2} \cdot \mathrm{h}^{-1}\end{array}$ & $\begin{array}{l}\text { azithromycin, erythromycin, } \\
\text { ofloxacin, sulfamethoxazole, } \\
\text { trimethoprim, acetaminophen, } \\
\text { diclofenac, ibuprofen, etc. }\end{array}$ & $70-100$ \\
\hline [30] & $\begin{array}{l}\text { Synthetic water; } \\
\text { natural } \\
\text { water/UF/Resin/ } \\
\text { Coagulation }\end{array}$ & RO, BM30-400 (polyamide) & $\begin{array}{l}15.5 \text { bar, permeate flux } \\
0.039-0.05 \mathrm{~m}^{3} \cdot \mathrm{m}^{-2} \cdot \mathrm{h}^{-1}\end{array}$ & $\begin{array}{l}\text { acetaminophen, atrazine, } \\
\text { bisphenol A, caffeine, } \\
\text { carbamazepine, cotinine, } \\
\text { DEET, } 17 a \text {-ethinylestradiol, } \\
\text { gemfibrozil, ibuprofen, } \\
\text { lopressor, progesterone, } \\
\text { propylparaben, sulfamethoxazole, } \\
\text { triclosan, trimethoprim }\end{array}$ & $69-100$ \\
\hline [31] & MBR effluent & RO (polyamide) & $\begin{array}{l}21 \% \text { recovery, } 7 \text { bar, } \\
\text { flux } 0.012 \mathrm{~m}^{3} \cdot \mathrm{m}^{-2} \cdot \mathrm{h}^{-1}\end{array}$ & $\begin{array}{l}\text { amoxicillin, atenolol, } \\
\text { caffeine, carbamazepine, } \\
\text { dilantin, iopromide, etc. }\end{array}$ & $95-100$ \\
\hline [32] & $\begin{array}{l}\text { Synthetic water, } \\
\text { Ontário } \\
\text { lake/resin/cation }\end{array}$ & $\begin{array}{l}\text { NF, NE4040-70 } \\
\text { (polyamide) }\end{array}$ & $\begin{array}{c}50 \% \text { recovery, } 3.45-4.14 \text { bar, } \\
\text { permeate flow } \\
0.00061-0.00085 \mathrm{~m}^{3} \cdot \mathrm{h}^{-1} \\
\text { flux } 0.039-0.055 \mathrm{~m}^{3} \cdot \mathrm{m}^{-2} \cdot \mathrm{h}^{-1} \text {, } \\
\text { concentrate flow } \\
0.0018-0.0025 \mathrm{~m}^{3} \cdot \mathrm{h}^{-1}\end{array}$ & $\begin{array}{l}\text { acetaminophen, bisphenol A, } \\
\text { carbamazepine, clofibric } \\
\text { acid, diethylbestrol, estrone, } \\
17 \beta \text {-estradiol, estriol, } \\
\text { sulfamethoxazole }\end{array}$ & $20-95$ \\
\hline [33] & $\begin{array}{l}\text { Drinking water } \\
\text { Synthetic water }\end{array}$ & NF, Desal 5DK & 10 bar, $100 \%$ recovery, $6 \mathrm{~h}$ & $\begin{array}{l}\text { atrazine, isoproturon, diuron, } \\
\text { alachlor, chlorfenvinphos }\end{array}$ & $95-99$ \\
\hline [34] & Groundwater & NF, Desal 5DK & $10 \mathrm{bar}$, flux $0.0047 \mathrm{~m}^{3} \cdot \mathrm{m}^{-2} \cdot \mathrm{h}^{-1}$ & $\begin{array}{c}\text { atrazine, alachlor, } \\
\text { pentachlorophenol, estrone, } \\
17 \beta \text {-estraiol, } \\
\text { 17a-ethinylestradiol, } \\
\text { estriol, progesterone }\end{array}$ & $92-100$ \\
\hline
\end{tabular}

Reverse Osmosis (RO); Microfiltration (MF); Ultrafiltration (UF); Nanofiltration (NF); Polyvinylidene Fluoride (PVDF); Membrane Bioreactor (MBR); Flat Sheet (FS); Hollow fiber (HF); Forward Osmosis (FO); Sodium hypochlorite (NaOCl); Wastewater Treatment Plant (WWTP). 
In contrast, Chon et al. [26] analyzed removal of sulfametoxazole (hydrophilic) and found that this adsorption should be considered, since even though this substance has a negative charge, when in solution the membrane removal efficiency is low. Further according to them, micropollutants that have neutral charges but high hydrophobicity are easier to remove when using NF membranes, which have negative surface charge.

Therefore micropollutants can be classified into groups according to their $\mathrm{pKa}$ and LogKow values: neutral hydrophilic, neutral hydrophobic, ionic hydrophilic and ionic hydrophobic [26]. In this respect, for a hydrophilic membrane and a substance with negative charge, the fouling phenomenon helps to retain neutral hydrophobic substances (because the adsorbed layer on the membrane surface serves as an additional barrier) and ionic hydrophilic ones (due to electrostatic repulsion), as well as facilitating adsorption of neutral hydrophilic substances [25].

Different types of materials are used to produce membranes, but polymers are most commonly used for removal of micropollutants from wastewaters and sewage, because these membranes are less expensive, are versatile regarding conformation and have high separation performance [12] [14] [35] [36] [37].

For removal of micropollutants, the majority of researchers have used membranes made of materials specifically chosen to remove determined substances, such as polyamide membranes (Figure 1). These membranes have a negative charge when in contact with substances having neutral $\mathrm{pH}$, thus enhancing their retention of negatively charged compounds. Other types of membranes are also used for different objectives, such as those made of cellulose acetate, which are frequently used to treat effluents with high concentration of chlorine, reaching salt removal rates of $99.5 \%$ in desalination applications [12]. However, according to Klüpfel and Frimmel [38], RO membranes produced with cellulose acetate do not have satisfactory performance in removing metamitron, clofibric acid, atrazine and terbutaline.

In order to improve the effectiveness of polyethersulfone (PES) membranes for mi-cropollutant removal, Kaminska et al. [39] inserted "small amounts of single walled carbon nanotubes" in this membrane, which increased the adsorption of bisphenol A and nonylphenol. But, the authors warn about that increase of the pressure can diminish the removal, probably because the porosity of the membrane and the convection through it.

Some authors have investigated the removal of micropollutants by MSP on industrial scale. Sui et al. [15] analyzed the removal of 14 compounds at four WTS located in Beijing, China. According to them, all were detected in the inflows to the stations, with the most abundant being caffeine $\left(3.4-6.6 \mu \mathrm{g} \cdot \mathrm{L}^{-1}\right)$ and DEET $\left(0.6-1.2 \mu \mathrm{g} \cdot \mathrm{L}^{-1}\right)$. However, they also observed that the station having a tertiary treatment system composed of MF and NF membranes achieved removal rates above $90 \%$ for the majority of the compounds analyzed. The only compounds that were poorly removed, were caffeine $(50 \%-80 \%)$ and mefenamic acid $(0 \%-50 \%)$. 
Investigating the same types of membranes, Al-Rifai et al. [40] analyzed the removal of 13 micropollutants at a WTS. The substances with the highest concentrations in the inflow were salicylic acid, ibuprofen and bisphenol-A (6.3 $\left.38.5 \mu \mathrm{g} \cdot \mathrm{L}^{-1}\right)$. Despite these high incoming concentrations, only the last was not removed effectively, showing concentrations in the permeate of $20-464 \mathrm{ng} \cdot \mathrm{L}^{-1}$.

Garcia et al. [28] assessed the removal of 20 micropollutants at a WTS equipped with tertiary treatment with MF and RO membranes in sequence, finding that only ibuprofen and nonylphenol were not efficiently removed $(<30 \%)$, in contrast to the other substances $(>75 \%)$. Therefore, they decided to study the removal of the two former substances in a pilot plant having a membrane bioreactor (MBR) system followed by a MSP system, alternating with NF and RO membranes. The authors observed removal rates of $99 \%$. They concluded that the deterioration state of the membranes directly affects the removal of micropollutants.

The study of new processes on pilot scale provides important information, enabling the prevention of possible operating risks and extrapolation of costs to industrial scale [16] [36]. In this sense, various studies have investigated the treatment of effluents on this scale, with a growing number devoted specifically to removal of micropollutants (Figure 1).

Dolar et al. [23] investigated the removal of several micropollutants by reverse osmosis after passage through a MBR and observed that all the target compounds were below the limit of quantification. Likewise, Cartagena et al. [17] obtained high removal rates ( $>99 \%)$ of various classes of micropollutants in the permeates from NF and RO membranes. Corroborating these two studies, Rodriguez-Mozaz et al. [29] attained concentrations below $16 \mathrm{ng} \cdot \mathrm{L}^{-1}$ in a combined system of UF and RO membranes. According to the authors, the use of a MSP to remove micropollutants can be strongly recommended, because unlike AOPs, there is no formation of byproducts and the process also serves as a barrier to possible microorganisms coming from the previous biological system.

However, Sahar et al. [22] compared the removal of 11 micropollutants by RO after passage through two types of system: MBR and CAS-UF (a hybrid system of conventional activated sludge and ultrafiltration). The authors concluded that despite the high removal rates ( $>93 \%$ ), vestiges of the compounds analyzed were found in the permeate $\left(28-223 \mathrm{ng} \cdot \mathrm{L}^{-1}\right)$ as a result of adsorption on the membrane. This suggests that the employment of RO is not effective, so other processes like adsorption in activated carbon and AOPs should be examined.

\section{Advanced Oxidation Process}

AOP are characterized by the generation of hydroxyl radical (HO•), nonselective oxidant with high reaction potential $(\mathrm{Eo}=2.8 \mathrm{~V})$, able to degrade even the most complex organic structures. These processes can be divided into homogeneous (catalyst and substrate or only substrate forming a single phase) and heterogeneous (catalyst and substrate forming two or more phases, with the catalyst generally being a solid). In turn, the generation of hydroxyl radicals can occur in the 
presence or absence of ultraviolet radiation [41]. When the reaction is complete, the hydroxyl radicals degrade the organic molecules into $\mathrm{CO}_{2}, \mathrm{H}_{2} \mathrm{O}$ and inorganic ions [4] [42]. Figure 2 presents the most used and investigated AOP.

According Kommineni et al. [43], in the advanced oxidative processes, two oxidation stages are involved: (1) formation of strong oxidants and (2) the oxidizing reaction of these with organic contaminants in water. After the formation of HO•, two types of initial reactions are proposed, abstraction of the hydrogen atom, i.e. alkanes or alcohols, to form water or HO• adding in olefins or aromatics for the opening of the rings [44].

Many studies have been conducted of the removal of micropollutants from wastewaters by advanced oxidation processes. Table 2 lists these papers.

Ozonation is a process widely applied to treat wastewaters containing recalcitrant organic matter. This occurs due to the high oxidation power of ozone $(2.07$ $\mathrm{V})$, which acts directly on the pollutant molecules, transforming or eliminating them. It can also be combined with UV radiation and/or $\mathrm{H}_{2} \mathrm{O}_{2}$ treatment, increasing the oxidation potential. Ozone's mechanism of action involves direct reactions (ozonolysis) or indirect ones (generation of hydroxyl radicals) and its effectiveness is related to the $\mathrm{pH}$ of the sample [45] [46].

Some micropollutants have been studied for treatment by ozonation and AOP, presenting a removal percentage for bisphenol-A ranging from $60 \%$ to $100 \%$ by $\mathrm{O}_{3}$ and $52 \%$ to $85 \%$ by $\mathrm{S}_{2} \mathrm{O}_{8}-/ \mathrm{UV}-\mathrm{C}$ and $\mathrm{H}_{2} \mathrm{O}_{2} / \mathrm{UV}-\mathrm{C}$ (Table 2). Others have been found to be highly resistant, such as bezafibrate, with a removal rate of only $14 \%$ by $\mathrm{O}_{3}[15]$.

Choi et al. [47] performed bench and pilot scale tests with river water to remove bisphenol-A by ozonation. The initial bisphenol-A concentration in the water varied from 543 to $844 \mathrm{ng} \cdot \mathrm{L}^{-1}$. The authors tested different $\mathrm{O}_{3}$ doses $(1-10$ $\left.\mathrm{mg} \cdot \mathrm{L}^{-1}\right)$, with alkaline $\mathrm{pH}$, and after contact for 7 minutes obtained removal rates of $60 \%$ to $100 \%$. In turn, Gerrity et al. [48] used a combination of $\mathrm{O}_{3}$ and $\mathrm{H}_{2} \mathrm{O}_{2}$ with initial concentrations of $5 \mathrm{mg} \cdot \mathrm{L}^{-1}$ and $3.5 \mathrm{mg} \cdot \mathrm{L}^{-1}$, respectively, at $\mathrm{pH} 6.9$. After contact time of 5 minutes and bisphenol-A concentration of $43 \mathrm{ng} \cdot \mathrm{L}^{-1}$, they found removal rates greater than $78 \%$.

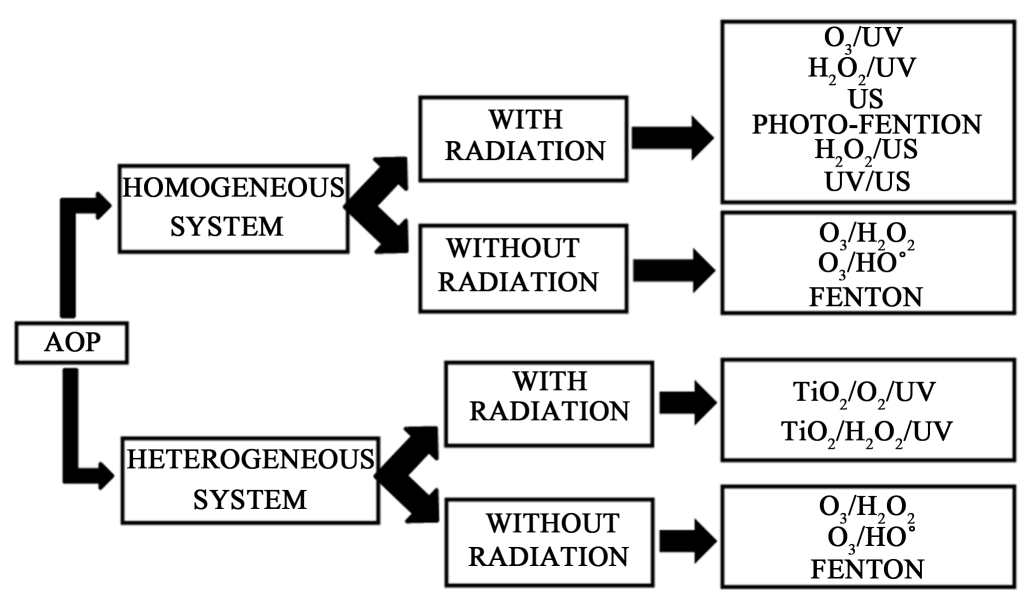

Figure 2. The most popular AOP. 
Table 2. Micropollutant removal from different matrixes by distinct membrane separation processes.

\begin{tabular}{|c|c|c|c|c|c|}
\hline Reference & Matrix & POA & Conditions & Micropollutant & Removal (\%) \\
\hline$[15]$ & $\begin{array}{l}\text { WTS } \\
\text { effluent after } \\
\text { ultrafiltration }\end{array}$ & $\mathrm{O}_{3}$ & $\begin{array}{c}{\left[\mathrm{O}_{3}\right]=5 \mathrm{mg} \cdot \mathrm{L}^{-1} ;} \\
\mathrm{pH} 6.5-8.0 ; 15 \mathrm{~min}\end{array}$ & $\begin{array}{l}\text { clofibric acid, mefenamic acid, bezafibrate, } \\
\text { caffeine, carbamazepine, diclofenac, } \\
\text { gemfibrozil, indomethacine, } \\
\text { metoprolol, DEET, trimethoprim }\end{array}$ & $0->90$ \\
\hline$[42]$ & $\begin{array}{l}\text { River } \\
\text { water }\end{array}$ & $\mathrm{O}_{3}$ & $\begin{array}{c}{\left[\mathrm{O}_{3}\right]=1-10 \mathrm{mg} \cdot \mathrm{L}^{-1}} \\
\mathrm{pH} 8.2-8.5 ; 7 \mathrm{~min}\end{array}$ & bisphenol-A & $60-100$ \\
\hline$[43]$ & $\begin{array}{c}\text { Secondary } \\
\text { treatment } \\
\text { effluent }\end{array}$ & $\mathrm{O}_{3} / \mathrm{H}_{2} \mathrm{O}_{2}$ & $\begin{array}{c}{\left[\mathrm{O}_{3}\right]=5 \mathrm{mg} \cdot \mathrm{L}^{-1}} \\
{\left[\mathrm{H}_{2} \mathrm{O}_{2}\right]=3.5 \mathrm{mg} \cdot \mathrm{L}^{-1}} \\
\text { pH } 6.9 ; 5 \mathrm{~min}\end{array}$ & $\begin{array}{l}\text { atenolol, atorvastatin, atrazine, } \\
\text { benzophenone, bisphenol-a, caffeine, } \\
\text { carbamazepine, diazepam, diclofenac, } \\
\text { estradiol, estrone, ethynylestradiol, } \\
\text { progesterone, testosterone, naxopren, } \\
\text { ibuprofen, triclosan, trimethoprim, etc. }\end{array}$ & $13->99$ \\
\hline$[45]$ & $\begin{array}{l}\text { Secondary } \\
\text { treatment } \\
\text { effluent }\end{array}$ & $\mathrm{O}_{3}$ & $\begin{array}{l}{\left[\mathrm{O}_{3}\right]=3 \mathrm{mg} \cdot \mathrm{L}^{-1}} \\
\mathrm{pH} 2.0 ; 27 \mathrm{~min}\end{array}$ & $\begin{array}{l}\text { thymol, triclosan, ibuprofen, naproxen, } \\
\text { ketoprofen, fenoprofen, mefenamic acid, } \\
\text { propylphenazone, crotamiton, } \\
\text { carbamazepine, diethyltoluamide, etc. }\end{array}$ & $>80$ \\
\hline [47] & $\begin{array}{l}\text { Synthetic } \\
\text { water }\end{array}$ & $\begin{array}{l}\mathrm{UV} ; \mathrm{UV} / \mathrm{H}_{2} \mathrm{O}_{2} ; \mathrm{O}_{3} \\
\mathrm{O}_{3} / \mathrm{H}_{2} \mathrm{O}_{2} ; \mathrm{O}_{3} / \mathrm{UV} \\
\mathrm{O}_{3} / \mathrm{UV} / \mathrm{H}_{2} \mathrm{O}_{2}\end{array}$ & $\begin{array}{c}{\left[\mathrm{O}_{3}\right]=0.33-1.31 \mathrm{mg} \cdot \mathrm{L}^{-1}} \\
{\left[\mathrm{H}_{2} \mathrm{O}_{2}\right]=20-60 \mathrm{mg} \cdot \mathrm{L}^{-1}} \\
\text { pH } 6.5 ; 15-75 \mathrm{~min}\end{array}$ & estrone & 100 \\
\hline$[48]$ & $\begin{array}{l}\text { Synthetic } \\
\text { water }\end{array}$ & $\mathrm{O}_{3} / \mathrm{TiO}_{2} / \mathrm{UV}-\mathrm{A}$ & $\begin{array}{c}{\left[\mathrm{O}_{3}\right]=10 \mathrm{mg} \cdot \mathrm{L}^{-1}} \\
{\left[\mathrm{TiO}_{2}\right]=1500 \mathrm{mg} \cdot \mathrm{L}^{-1} ; \mathrm{pH} 5.0} \\
\lambda=313 \mathrm{~nm} ; 30 \mathrm{~min}\end{array}$ & diclofenac & 100 \\
\hline [49] & $\begin{array}{l}\text { Synthetic } \\
\text { water }\end{array}$ & Electro-fenton & $\begin{array}{c}{\left[\mathrm{Fe}^{3+}\right]=0.1 \mathrm{mM}} \\
{\left[\mathrm{Cu}^{2+}\right]=4 \mathrm{mM} ; \mathrm{pH} 3.0 ; 22 \mathrm{~min}}\end{array}$ & atrazine & 100 \\
\hline [50] & $\begin{array}{l}\text { Synthetic } \\
\text { water }\end{array}$ & $\begin{array}{l}\mathrm{UV} / \mathrm{H}_{2} \mathrm{O}_{2} \\
\mathrm{UV} / \mathrm{S}_{2} \mathrm{O}_{8}^{2-} \\
\mathrm{UV} / \mathrm{HSO}_{5}^{-}\end{array}$ & $\begin{array}{c}{\left[\mathrm{H}_{2} \mathrm{O}_{2}\right]=20-190 \mathrm{uM}} \\
{\left[\mathrm{S}_{2} \mathrm{O}_{8}^{2-}\right]=0-100 \mathrm{uM}} \\
{\left[\mathrm{HSO}_{5}^{-}\right]=0-100 \mathrm{uM}} \\
\text { pH } 3.0-11.0\end{array}$ & atrazine & 100 \\
\hline [51] & $\begin{array}{l}\text { Secondary } \\
\text { treatment } \\
\text { effluent }\end{array}$ & $\mathrm{UV} / \mathrm{H}_{2} \mathrm{O}_{2}$ & $\begin{array}{c}{\left[\mathrm{H}_{2} \mathrm{O}_{2}\right]=4-16 \mathrm{mg} \cdot \mathrm{L}^{-1} ;} \\
\mathrm{UV} \text { dose }=24.48-122.4 \mathrm{~kJ} \cdot \mathrm{m}^{-2} ; \\
\quad 60-600 \mathrm{~min}\end{array}$ & $\begin{array}{c}17 \beta \text {-estradiol, } \\
17 \alpha \text {-esthinylestradiol and estriol }\end{array}$ & $91 \%-100 \%$ \\
\hline$[52]$ & $\begin{array}{l}\text { Distilled } \\
\text { water }\end{array}$ & $\begin{array}{c}\mathrm{TiO}_{2} / \mathrm{UV} \\
\mathrm{TiO}_{2} / \mathrm{H}_{2} \mathrm{O}_{2} / \mathrm{UV} \\
\mathrm{UV}\end{array}$ & - & Tylosin & $>98$ \\
\hline [53] & $\begin{array}{l}\text { Tap water } \\
\text { and surface water }\end{array}$ & $\mathrm{TiO}_{2} / \mathrm{UV}-\mathrm{C}$ & $\begin{array}{c}{\left[\mathrm{TiO}_{2}\right]=500 \text { and } 750 \mathrm{mg} \cdot \mathrm{L}^{-1} ;} \\
\text { UV-C radiation: } \\
1.04-2.08 \mathrm{~W} \cdot \mathrm{L}^{-1} ; 180-300 \mathrm{~min}\end{array}$ & diclofenac & $56-100$ \\
\hline$[54]$ & $\begin{array}{c}\text { Secondary } \\
\text { treatment } \\
\text { effluent }\end{array}$ & $\begin{array}{c}\mathrm{TiO}_{2} / \mathrm{UV} \\
\mathrm{HSO}_{5}^{-} / \mathrm{Fe}^{2+} / \mathrm{UV}\end{array}$ & $\begin{array}{l}{\left[\mathrm{TiO}_{2}\right]=50-2000 \mathrm{mg} \cdot \mathrm{L}^{-1}} \\
{[\mathrm{Fe}]=0.1 \mathrm{mM}} \\
{\left[\mathrm{HSO}_{5}^{-}\right]=0.025-0.5 \mathrm{mM}}\end{array}$ & $\begin{array}{l}\text { Sulfamethoxazole, diclofenac, } \\
\text { carbamazepine, clothianidin, } \\
\text { mesotrione and bifenthrin }\end{array}$ & 100 \\
\hline$[55]$ & $\begin{array}{l}\text { Synthetic } \\
\text { water }\end{array}$ & $\mathrm{MW} / \mathrm{UV} / \mathrm{H}_{2} \mathrm{O}_{2}$ & $\begin{array}{c}{\left[\mathrm{H}_{2} \mathrm{O}_{2}\right]=0-500 \mathrm{mg} \cdot \mathrm{L}^{-1}} \\
\text { pH } 5.0-7.0 \\
\lambda=200-320 \mathrm{~nm} ; 20 \mathrm{~min}\end{array}$ & atrazine & 100 \\
\hline [56] & $\begin{array}{l}\text { Secondary } \\
\text { treatment } \\
\text { effluent }\end{array}$ & $\begin{array}{c}\mathrm{UV} ; \mathrm{UV} / \mathrm{H}_{2} \mathrm{O}_{2} \\
\mathrm{Fe}^{2+} / \mathrm{H}_{2} \mathrm{O}_{2} \\
\mathrm{Fe}^{2+} / \mathrm{H}_{2} \mathrm{O}_{2} / \mathrm{UV} \\
\mathrm{Fe}^{2+} / \mathrm{H}_{2} \mathrm{O}_{2} / \mathrm{UV}_{290}\end{array}$ & $\begin{array}{c}{\left[\mathrm{H}_{2} \mathrm{O}_{2}\right]=0-50 \mathrm{mg} \cdot \mathrm{L}^{-1} ;} \\
{\left[\mathrm{Fe}^{2+}\right]=0-5 \mathrm{mg} \cdot \mathrm{L}^{-1} ;} \\
\mathrm{pH} 7.0-7.42 ; \\
\lambda=254-290 \mathrm{~nm} ; 10-90 \mathrm{~min}\end{array}$ & $\begin{array}{l}\text { atenolol, atrazine, azithromycin, } \\
\text { bezafibrate, benzotriazole, carbamazepine, } \\
\text { ciprofloxacin, clarithromycin, } \\
\text { diclofenac, diuron, gemfibrozil, ibuprofen, } \\
\text { ketoprofen, iopamidol, metformin, } \\
\text { methylbenzotriazole, metoprolol, etc. }\end{array}$ & $0-100$ \\
\hline
\end{tabular}




\section{Continued}

\begin{tabular}{|c|c|c|c|c|c|}
\hline$[57]$ & $\begin{array}{l}\text { Synthetic } \\
\text { water }\end{array}$ & Fenton & $\begin{array}{c}{\left[\mathrm{Fe}^{6+}\right]=2.52 \mathrm{~mol} \cdot \mathrm{L}^{-1}} \\
\mathrm{pH} 7.0 ; 10 \mathrm{~min}\end{array}$ & bisphenol A & 97.5 \\
\hline [58] & $\begin{array}{l}\text { Synthetic } \\
\text { water }\end{array}$ & $\mathrm{O}_{3}$ & $\begin{array}{c}{\left[\mathrm{O}_{3}\right]=8.3-15 \mathrm{mg} \cdot \mathrm{L}^{-1}} \\
\mathrm{pH} 8.4 ; 15-45 \mathrm{~min}\end{array}$ & $\begin{array}{c}\text { hexylcinnamic aldehyde, } \\
\text { benzophenone-3, bisphenol-a, } \\
\text { butylparaben, caffeine, } \\
\text { ethylparaben, galaxolide, } \\
\text { 4-methylbenzylidene-camphor, } \\
\text { methylparaben, nonylphenol, } \\
\text { propylparaben, tonalide, triclosan }\end{array}$ & $95->99$ \\
\hline [59] & Sewage & $\mathrm{O}_{3} / \mathrm{US}$ & $\begin{array}{c}{\left[\mathrm{O}_{3}\right]=7-12 \mathrm{mg} \cdot \mathrm{L}^{-1}} \\
\mathrm{US}=0 \%-100 \% ; 1-13 \mathrm{~min}\end{array}$ & $\begin{array}{c}\text { acetaminophen, bezafibrate, } \\
\text { ciprofloxacin, clarithromycin, } \\
\text { diclofenac, gemfibrozil, } \\
\text { ibuprofen, naproxen, ofloxacin, } \\
\text { salicylic acid, sulfamethazine, } \\
\text { sulfametoxazole, } \\
\text { venlafaxine, furosemida, } \\
\text { carbamazepine, benzoilecgonine, etc. }\end{array}$ & $90-100$ \\
\hline$[60]$ & $\begin{array}{l}\text { WWTS } \\
\text { effluent }\end{array}$ & $\mathrm{UV} / \mathrm{H}_{2} \mathrm{O}_{2}$ & {$\left[\mathrm{H}_{2} \mathrm{O}_{2}\right]=7.8 \mathrm{mg} \cdot \mathrm{L}^{-1} ; 5 \mathrm{~min}$} & $\begin{array}{l}\text { antipyrine, diclofenac, ketoprofen, } \\
\text { isopropylantipyrine, indomethacine, } \\
\text { fenoprofen, naproxen, mefenamic acid, } \\
\text { ethenzamide, acetaminophen, } \\
\text { disopyramide, atenolol, propanolol, } \\
\text { metoprolol, chlortetracycline, } \\
\text { norfloxacin, sulfamethoxazole, etc. }\end{array}$ & $60-100$ \\
\hline$[61]$ & Synthetic water & $\mathrm{O}_{3}$ & {$\left[\mathrm{O}_{3}\right]=6 \mathrm{mmol} ; \mathrm{pH} 3 ; 25 \mathrm{~min}$} & bisphenol A & $87-99.5$ \\
\hline$[62]$ & $\begin{array}{l}\text { Synthetic water } \\
\text { and WWTP } \\
\text { effluent }\end{array}$ & $\mathrm{UV} / \mathrm{H}_{2} \mathrm{O}_{2} ; \mathrm{UV} / \mathrm{S}_{2} \mathrm{O}_{8}{ }^{2-}$ & $\begin{array}{c}{\left[\mathrm{S}_{2} \mathrm{O}_{8}^{2-}\right]=\left[\mathrm{H}_{2} \mathrm{O}_{2}\right]=4 \mathrm{mM}} \\
\text { pH } 6.0\end{array}$ & ibuprofen & 92.2 \\
\hline [63] & $\begin{array}{l}\text { Synthetic } \\
\text { water }\end{array}$ & $\begin{array}{l}\mathrm{H}_{2} \mathrm{O}_{2} / \mathrm{UV} \\
\mathrm{Fe}^{3+} / \mathrm{UV} \\
\mathrm{Fe}^{2+} / \mathrm{H}_{2} \mathrm{O}_{2} \\
\mathrm{Fe}^{3+} / \mathrm{H}_{2} \mathrm{O}_{2}\end{array}$ & $\begin{array}{c}{\left[\mathrm{Fe}^{3+}\right]=0.06-0.5 \mathrm{mM}} \\
{\left[\mathrm{Fe}^{2+}\right]=0.28 \mathrm{mM}} \\
{\left[\mathrm{H}_{2} \mathrm{O}_{2}\right]=0.14-5 \mathrm{mM}} \\
\text { pH 3.0; } 0.66-6.66 \mathrm{~min}\end{array}$ & atrazine & 90 \\
\hline$[64]$ & $\begin{array}{l}\text { Synthetic } \\
\text { water }\end{array}$ & $\mathrm{O}_{3}$ & $\begin{array}{c}{\left[\mathrm{O}_{3}\right]=14-20 \mathrm{uM} ;} \\
{[\mathrm{pCBA}]=0.25-0.34 \mathrm{uM} ; \mathrm{pH} 9.0}\end{array}$ & nonylphenol, octylphenol & 85 \\
\hline$[65]$ & River water & $\mathrm{O}_{3} / \mathrm{UV}$ & $\begin{array}{c}{\left[\mathrm{O}_{3}\right]=45 \mathrm{mg} \cdot \mathrm{L}^{-1}} \\
\mathrm{pH} 7.0 ; 30 \mathrm{~min}\end{array}$ & diethyl phthalate & 100 \\
\hline$[66]$ & $\begin{array}{l}\text { Synthetic } \\
\text { water }\end{array}$ & $\begin{array}{l}\mathrm{S}_{2} \mathrm{O}_{8}^{2-} / \mathrm{UV}-\mathrm{C} \\
\mathrm{H}_{2} \mathrm{O}_{2} / \mathrm{UV}-\mathrm{C}\end{array}$ & $\begin{array}{c}{\left[\mathrm{S}_{2} \mathrm{O}_{8}^{2-}\right]=2.5 \mathrm{mM}} \\
{\left[\mathrm{H}_{2} \mathrm{O}_{2}\right]=2.5 \mathrm{mM}} \\
\mathrm{pH} 6.5 ; 120 \mathrm{~min}\end{array}$ & bisphenol A & $52-85$ \\
\hline [67] & $\begin{array}{l}\text { Synthetic water } \\
\text { and Effluent }\end{array}$ & $\mathrm{O}_{3} ; \mathrm{UV} / \mathrm{H}_{2} \mathrm{O}_{2}$ & $\begin{array}{c}{\left[\mathrm{O}_{3}\right]=5 \mathrm{mg} \cdot \mathrm{L}^{-1}} \\
{\left[\mathrm{H}_{2} \mathrm{O}_{2}\right]=1000 \mathrm{mg} \cdot \mathrm{L}^{-1}} \\
\text { pH } 7.0-8.5 ; 60 \mathrm{~min}\end{array}$ & $\begin{array}{l}\text { bisphenol a, ciprofloxacin, } \\
\text { metoprolol, sulfamethoxazole }\end{array}$ & 100 \\
\hline$[68]$ & $\begin{array}{l}\text { Synthetic } \\
\text { water }\end{array}$ & US & $\begin{array}{c}{\left[\mathrm{HCO}_{3}^{-}\right]=0-10 \mathrm{mM}} \\
2 \mathrm{~kW}(20 \mathrm{kHz}) \\
\mathrm{pH} 7 ; 0 ; 20 \mathrm{~min} ; 20^{\circ} \mathrm{C}\end{array}$ & $\begin{array}{c}\text { estradiol, estrone, estriol, } \\
\text { ethynylestradiol }\end{array}$ & $10-70$ \\
\hline
\end{tabular}

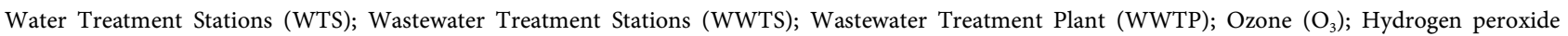
$\left(\mathrm{H}_{2} \mathrm{O}_{2}\right)$; Ultraviolet (UV); Ultraviolet cancer (UV-C); Ultraviolet age (UV-A); Titanium dioxide $\left(\mathrm{TiO}_{2}\right)$; Iron ion II $\left(\mathrm{Fe}^{2+}\right)$; Iron ion III $\left(\mathrm{Fe}^{3+}\right)$; Iron ion VI $\left(\mathrm{Fe}^{6+}\right)$; Copper ion II $\left(\mathrm{Cu}^{2+}\right)$; Persulfate ion $\left(\mathrm{S}_{2} \mathrm{O}_{8}^{2-}\right)$; Peroxomonosulfate ion ( $\left.\mathrm{HSO}_{5}^{1-}\right)$; Microwave (MW); Ultrasound (US); p-chlorobenzoic acid (pCBA). 
Lee et al. [49] studied the removal of 25 drugs in hospital effluent by ozonation. They observed that the removal percentages of these compounds at $\mathrm{pH}$ of 7 and 8 depended on the initial ozone dose and that the addition of $\mathrm{H}_{2} \mathrm{O}_{2}$ enhanced the reaction efficiency, due to the generation of hydroxyl radicals. Nevertheless, they also observed that when the $\mathrm{gO}_{3} / \mathrm{gDOC}$ ratio was below the organic matter quickly consumed the ozone and the addition of $\mathrm{H}_{2} \mathrm{O}_{2}$ did not increase the degradation of these compounds.

Nakada et al. [50] investigated the efficiency or removing 24 pharmaceutical compounds by ozonation in samples from a sewage treatment plant in Japan. They observed that the efficiency of ozonation was related to the chemical structure of the compound, because the action mechanism of ozone is favored in the presence of double bonds, $\mathrm{C}=\mathrm{C}$ or aromatic chains with donor electrons. However, they did not observe the same results in compounds containing an amide group. Nearly all the compounds were efficiently removed (>80\%) with combination of the two processes, the only exceptions being carbamazepine and diethyltoluamide.

Hydrogen peroxide and ultraviolet radiation are used to degrade some $\mathrm{mi}$ cropollutant in water and wastewater. The formation of $\mathrm{HO} \bullet$ by $\mathrm{UV} / \mathrm{H}_{2} \mathrm{O}_{2}$ process occurs according to the reactions 1, 2 and 3 [51].

$$
\begin{gathered}
\mathrm{H}_{2} \mathrm{O}_{2} \stackrel{\text { hv }}{\longrightarrow} 2 \cdot \mathrm{OH} . \\
\mathrm{H}_{2} \mathrm{O}_{2} \leftrightarrow \mathrm{HO}_{2}^{-}+\mathrm{H}^{+} . \\
\mathrm{HO}_{2}^{-} \stackrel{\text { hv }}{\longrightarrow} \cdot \mathrm{OH}+\mathrm{O}^{-} .
\end{gathered}
$$

Sarkar et al. [69] carried out laboratory tests for removal of $5 \mathrm{mg} \cdot \mathrm{L}^{-1}$ of estrone from water by different AOP, namely $\mathrm{UV}, \mathrm{UV} / \mathrm{H}_{2} \mathrm{O}_{2}, \mathrm{O}_{3}, \mathrm{O}_{3} / \mathrm{H}_{2} \mathrm{O}_{2}, \mathrm{O}_{3} / \mathrm{UV}$ and $\mathrm{O}_{3} / \mathrm{UV} / \mathrm{H}_{2} \mathrm{O}_{2}$. Under almost all the conditions tested, it was possible to remove $100 \%$ of the estrone from the water.

Aguinaco et al. [70] conducted tests to remove diclofenac with ultrapure water in an acid medium by $\mathrm{O}_{3} / \mathrm{TiO}_{2} / \mathrm{UVA}$, with initial $\mathrm{O}_{3}$ and $\mathrm{TiO}_{2}$ concentrations of $10 \mathrm{mg} \cdot \mathrm{L}^{-1}$ and $1.5 \mathrm{~g} \cdot \mathrm{L}^{-1}$, respectively, wavelength of $313 \mathrm{~nm}$ and contact time of $30 \mathrm{~min}$, achieving $100 \%$ removal. In turn, Sui et al. [15] performed tests to treat the effluent from a WWTS after ultrafiltration containing from 100 to 1000 $\mathrm{ng} \cdot \mathrm{L}^{-1}$ of the micropollutant in question. With $5 \mathrm{mg} \cdot \mathrm{L}^{-1}$ of $\mathrm{O}_{3}, \mathrm{pH} 6.5-8.0$ and contact time of $15 \mathrm{~min}$, the removal percentage was higher than $90 \%$.

Balci et al. [71] studied the Electro-Fenton process and concluded that 0.1 $\mathrm{mM}$ of $\mathrm{Fe}^{3+}$ with $4 \mathrm{mM}$ of $\mathrm{Cu}^{2+}$ was the most effective catalytic system in this process. Khan et al. [72] assessed the degradation of atrazine. They observed that the $\mathrm{UV} / \mathrm{S}_{2} \mathrm{O}_{8}^{2-}$ process accelerates the degradation of this micropollutant in the presence of the radical sulfate $\left(\mathrm{k}=2.59 \times 109 \mathrm{M}^{-1} \cdot \mathrm{s}^{-1}\right)$ and the radical hydroxyl $\left(\mathrm{k}=2.25 \times 109 \mathrm{M}^{-1} \cdot \mathrm{s}^{-1}\right)$.

Silva et al. [73] investigating the removal of $17 \beta$-estradiol, $17 \alpha$-ethinylestradiol and estriol by AOP and RO process observed that the $\mathrm{H}_{2} \mathrm{O}_{2} / \mathrm{UV}\left(4 \mathrm{mg} \cdot \mathrm{L}^{-1} \mathrm{H}_{2} \mathrm{O}_{2}\right.$ and $122.4 \mathrm{~kJ} \cdot \mathrm{m}^{-2}$ ) eliminated the presence of the two first estrogens and $91 \%$ of estriol. The authors concluded that AOP was effective although the membrane 
process, which couldn't remove estrogens tested.

WTS are among the leading sources of emerging contaminants, because they receive all the effluents from generating sources, such as residences, hospitals and factories. Many of these contaminants are not removed by conventional processes, making it necessary to use tertiary treatment methods, which can be used alone or in combination, such as nanofiltration, reverse osmosis, advanced oxidation processes and/or ozonation, solar photo-Fenton, among others [18] [37] [74] [75] [76] [77] [78]. The use of AOP has been widely studied in synthetic water and surface water in order to evaluate the efficiency of removal as well as the detection of degradation products and the kinetics involved [79] [80] [81] [82] [83]. However, there are few studies that discuss the removal of micropollutants present in sewage, as well as the endocrine disruptors.

Thus, many studies can achieve removals up to $99 \%$ of estrogens in WTS effluents, but it is necessary to study the best relation of the variants (like UV doses, $\mathrm{H}_{2} \mathrm{O}_{2}$ concentration, $\mathrm{O}_{3}$ doses and catalysts concentration) to avoid competitive reactions that diminish the efficiency of the $\mathrm{UV} / \mathrm{H}_{2} \mathrm{O}_{2}$ process [75] [81] [82].

\section{Integrated Processes}

WWTS are one of the main sources of emerging contaminants in the environment, as they receive effluents from differences sources such as residences, hospitals, industries, etc. Many of these contaminants are not removed by conventional processes or only one technique (as have been shown in Table 1 and Table 2). So, it's make necessary the use of integrated processes that could reach high levels of quality of the treated water. Several works studied integrated process to remove micropollutant from water, such as nanofiltration, reverse osmosis, AOP, ozone, activated carbon (AC), membrane bioreactor (MBR), among others (Table 3). These articles have investigated the use of integrated tertiary treatments with a main objective being reduction of energy costs while at the same time achieving satisfactory contaminant removal rates [76].

Another use of integrated processes is the treatment of concentrate stream generated from membrane process. In these works, the concentrated pollutants was treated by AOP [18] [75] [83] or ozone as pre-treatment for membranes [84].

Schaar et al. [85] observed in a WWTS in Austria that the installation of a pilot-scale ozonation facility $\left(0.6 \mathrm{O}_{3} \mathrm{~g} / \mathrm{gDOC}\right)$ after biological treatment resulted in removal of most micropollutants, such as carbamazepine and diclofenac.

Laoufi et al. [86] studied the photodegradation of tylosin, a veterinary antibiotic, using a photoreactor containing $\mathrm{TiO}_{2}$. The antibiotic was completely removed after 7 hours of illumination; the best degradation was obtained at $\mathrm{pH} 3$. More than $98 \%$ of tylosin has been oxidized after an irradiation time of 7 hours at the optimum position of UV light.

The combined photocatalytic membrane reactor and $\mathrm{TiO}_{2}$ nanoparticles was evaluated by Plakas et al. [87] to degradation of the pharmaceutical diclofenac. The authors achieved diclofenac removal between $56 \%$ and $100 \%$, whereas $52 \%$ TOC removal was recorded. 
Table 3. Integrated processes for microlpollutant removal.

\begin{tabular}{|c|c|c|}
\hline Reference & Integrated processes & Rejection/Removal of several micropollutants \\
\hline \multirow{2}{*}{ [17] } & $\mathrm{MBR}->\mathrm{NF}$ & $50 \%-99.9 \%$ \\
\hline & MBR - > RO & $57.1 \%-99.9 \%$ \\
\hline \multirow{3}{*}{ [18] } & NF - >UV & $\approx 49 \%$ (30 min) \\
\hline & $\mathrm{NF}->\mathrm{O}_{3}$ & $\approx 99 \%(10-20 \mathrm{~min})$ \\
\hline & $\mathrm{NF}->\mathrm{UV} / \mathrm{O}_{3}$ & $85 \%-99 \%(5 \mathrm{~min})$ \\
\hline [19] & $\mathrm{MBR}->\mathrm{NF}$ & $15 \%-99 \%$ \\
\hline \multirow{2}{*}{ [21] } & $\mathrm{GAC} / \mathrm{MF}$ & $54.6 \%-89.1 \%$ \\
\hline & GAC/MF - >NF & $>99 \%$ \\
\hline \multirow{2}{*}{ [22] } & $\mathrm{MBR}->\mathrm{RO}$ & \multirow{2}{*}{$93.2 \%-99.6 \%$} \\
\hline & $\mathrm{AS}->\mathrm{UF}->\mathrm{RO}$ & \\
\hline [26] & Coagulation $->\mathrm{DF}->\mathrm{UF}->\mathrm{RO}$ & $90 \%-99 \%$ \\
\hline \multirow{3}{*}{ [28] } & $\mathrm{MF}->\mathrm{RO}$ & $15 \%-95 \%$ \\
\hline & $\mathrm{MBR}->\mathrm{RO}$ & $95 \%-99 \%$ \\
\hline & $\mathrm{MBR}->\mathrm{NF}$ & $95 \%-99 \%$ \\
\hline \multirow{2}{*}{ [29] } & AS - > MF - > RO & $100 \%$ \\
\hline & AS - >UV - >Cl & $48 \%-100 \%$ \\
\hline \multirow{2}{*}{ [32] } & $\mathrm{UF}->\mathrm{NF}$ & $39 \%-90 \%$ \\
\hline & IER - >NF & $20 \%-85 \%$ \\
\hline [34] & $\mathrm{UV}_{254}->\mathrm{NF}$ & $40 \%-100 \%$ \\
\hline [76] & $\mathrm{MF}->\mathrm{RO}->\mathrm{UV}+\mathrm{H}_{2} \mathrm{O}_{2}$ & $99 \%$ \\
\hline [87] & $\mathrm{TiO}_{2}$ nanoparticles - >UF & $50 \%-100 \%$ \\
\hline [83] & $\mathrm{MF}->\mathrm{RO}->\mathrm{GAC} / \mathrm{MF}$ & $80 \%-99 \%$ \\
\hline [84] & $\mathrm{O}_{3}->\mathrm{NF}$ & $100 \%$ \\
\hline
\end{tabular}

Granular Activated Carbon (GAC); Microfiltration (MF); Nanofiltration (NF); Ultraviolet (UV); Ozone $\left(\mathrm{O}_{3}\right)$; Titanium dioxide $\left(\mathrm{TiO}_{2}\right)$; Ultrafiltration (UF); Ion Exchange Resins (IER); Membrane Bioreactor (MBR); Disk Filtration (DF); Reverse Osmosis (RO); Activated Sludge (AS); Chlorination (Cl); Ultrafiltration (UF).

Advanced oxidation system using solar irradiation/peroxymonosulfate (PMS)/ $\mathrm{Fe}^{2+}$ to degrade many organic micropollutants was studied by Ahmed et al. [88] and compared with the $\mathrm{UV} / \mathrm{TiO}_{2}$ oxidative system. The authors showed that the $\mathrm{PMS} / \mathrm{Fe}(\mathrm{II}) / \mathrm{UV}$-Vis advanced oxidation system has better kinetic performances over $\mathrm{TiO}_{2} / \mathrm{UV}$-Vis system for six organic micropollutants removal in WWTP effluents mainly due to the higher selectivity in reactivity of $\mathrm{SO}_{4} \bullet^{-}$with respect to $\mathrm{HO} \bullet$ in organic matrices. A molar ratio PMS:Fe(II) of 2:1 was found to be optimum for a full mineralization of investigated compounds in $30 \mathrm{~min}$.

\section{Discussion and Conclusion}

This review summarized the findings of many works in the literature that had investigated Membrane and AOP to remove micropollutants from various wastewater sources.

Several studies have associated the presence of micropollutants in water/ wastewater and the adverse effects in the environment. It is known that the most 
organic micropollutants are persistent and show the difficult degradation. The low concentrations that they are detected, are also present in surface water in concentrations of $\mathrm{ng} \cdot \mathrm{L}^{-1}$; the complete removal is hard to achieve.

Membrane processes, in particular nanofiltration and reverse osmosis, have been reported as promising technologies for the removal of micropollutants in water. The works reviewed in this paper showed satisfactory results and high removal efficiency values for many classes of micropollutants such as pharmaceuticals, personal care products, hormones and pesticides. Because of the affinity of some micropollutants with the membrane's surface, some authors have associated separation process with pollutant adsorption phenomena on the membrane. However, this phenomenon can reduce the removal efficiency by occurrence of a diffusive process and subsequent desorption of micropollutant at permeate. In some studies, it was found that the best micropollutant removal efficiency occurs at $\mathrm{pH}$ values above the $\mathrm{pKa}$ of the compound, for reasons of electrical repulsion with the membrane. It was also found that the removal of micropollutants membrane could be related to the size of the molecules by the exclusion phenomenon.

AOP has been studied for degradation of several classes of micropollutants, especially because they have advantages such as the mineralization capacity and no generation of a concentrated stream. However, it is observed that although there is the effective micropollutant degradation, the formation of by-products could lead to an increase in antagonistic effects such as toxicity and estrogenic activity. The best operation conditions for complete mineralization of micropollutant and degradation kinetics which has been the key to the AOP are effective in the treatment of water and wastewater. From AOP systems, the most important point related by several authors is the best relation of the variants that have to be applied to achieve high removals and avoid unnecessary waste with reactants. Also, depending on the micropollutants and the type of matrix, a sequence of advanced treatments' processes has to be considered.

\section{Acknowledgements}

The authors want to thank CAPES for research founding, which made this project possible.

\section{References}

[1] USEPA (2016) What's Endocrine Disruption? https://www.epa.gov/endocrine-disruption/what-endocrine-disruption

[2] Birkett, J.W. and Lester, J.N. (2003) Endocrine Disrupters in Wastewater and Sludge Treatment Processes. Lewis Publishers, London, England.

[3] Baird, C. and Cann, M. (2011) Química Ambiental. 4th Edition, Bookman, Porto Alegre.

[4] Luo, Y., Guo, W., Ngo, H.H., Nghiemb, L.D., Hai, F.I., Zhang, J., Liang, S. and Wang, X.C. (2014) A Review on the Occurrence of Micropollutants in the Aquatic Environment and Their Fate and Removal during Wastewater Treatment. Science of the Total Environment, 473, 619-641. 
[5] Hamid, H. and Eskicioglu, C. (2012) Fate of Estrogenic Hormones in Wastewater and Sludge Treatment: A Review of Properties and Analytical Detection Techniques in Sludge Matrix. WaterResource, 46, 5813-5833.

[6] Bila, D.M. and Dezotti, M. (2003) Fármacos no meio ambiente. Química Nova, 26, 523-530. https://doi.org/10.1590/S0100-40422003000400015

[7] Bila, D.M. and Dezotti, M. (2007) Desreguladores endócrinos no ambiente: Efeitos e consequências. Química Nova, 30, 651-666. https://doi.org/10.1590/S0100-40422007000300027

[8] Manahan, S.E. (2005) Environmental Chemistry. 8th Edition, CRC Press LLC, New York.

[9] Souza, N.C. (2011) Avaliação de micropoluentes emergentes em esgotos e águas superficiais (Assessment of Emerging Micropollutants in Sewage and Surface Water). Dissertation, Federal University of Ceará, Ceará (CE).

[10] Bolong Bolong, N., Ismail, A.F., Salim, M.R. and Matsuura, T. (2009) A Review of the Effects of Emerging Contaminants in Wastewater and Options of Their Removal. Desalination, 239, 229-246.

[11] Nath, K. (2008) Membrane Separation Processes. PHI Learning Pvt. Ltd., New Delhi.

[12] Baker, R.W. (2004) Membrane Technology and Applications. 2nd Edition, John Wiley \& Sons, Ltd., Hoboken. https://doi.org/10.1002/0470020393

[13] Mallevialle, J., Odendaal, P.E. and Wiesner, M.R. (1996) Water Treatment Membrane Processes. LyonnaisedesEaux-LdE, New York.

[14] Harbert, A.C., Borges, C.P. and Nobrega, R. (2003) Processos de Separação com Membranas [Membrane Separation Processes]. E-papers, Rio de Janeiro.

[15] Sui, Q., Huang, J., Deng, S., Yu, G. and Fan, Q. (2010) Occurrence and Removal of Pharmaceuticals, Caffeine and DEET in Wastewater Treatment Plants of Beijing, China. Water Research, 44, 417-426.

[16] Yangali-Quintanilla, V., Maeng, S.K., Fujioka, T., Kennedy, M. and Amy, G. (2010) Proposing Nanofiltration as Acceptable Barrier for Organic Contaminants in Water Reuse. Journal of Membrane Science, 362, 334-345.

[17] Cartagena, P., Kaddouri, M.E., Cases, V., Trapote, A. and Prats, D. (2013) Reduction of Emerging Micropollutants, Organic Matter, Nutrients and Salinity from Real Wastewater by Combined MBR-NF/RO Treatment. Separation and Purification Technology, 110, 132-143.

[18] Liu, P., Zhang, H., Feng, Y., Yang, F. and Zhang, J. (2014) Removal of Trace Antibiotics from Wastewater: A Systematic Study of Nanofiltration Combined with Ozone-Based Advanced Oxidation Processes. Chemical Engineering Journal, 240, 211-220.

[19] Chon, K., Kyong Shon, H. and Cho, J. (2012) Membrane Bioreactor and Nanofiltration Hybrid System for Reclamation of Municipal Wastewater: Removal of $\mathrm{Nu}$ trients, Organic Matter and Micropollutants. Bioresource Technology, 122, 181188.

[20] Simon, A., Nghiem, L.D., Le-Clech, P., Khan, S.J. and Drewes, J.E. (2009) Effects of Membrane Degradation on the Removal of Pharmaceutically Active Compounds (PhACs) by NF/RO Filtration Processes. Journal of Membrane Science, 340, 16-25.

[21] Shanmuganathan, S., Johir, M.A., Nguyen, T.V., Kandasamy, J. and Vigneswaran, S. (2015) Experimental Evaluation Microfiltration-Granular Activated Carbon (MFGAC)/Nano Filter Hybrid System in High Quality Water Reuse. Journal of Membrane Science, 476, 1-9. 
[22] Sahar, E., David, I., Gelman, Y., Chikurel, H., Aharoni, A., Messalem, R. and Brenner, A. (2011) The Use of RO to Remove Emerging Micropollutants Following CAS/UF or MBR Treatment of Municipal Wastewater. Desalination, 273, 142-147.

[23] Dolar, D., Gros, M., Rodriguez-Mozaz, S., Moreno, J., Comas, J., Rodriguez-Roda, I. and Barceló, D. (2012) Removal of Emerging Contaminants from Municipal Wastewater with an Integrated Membrane System, MBR-RO. Journal of Hazardous Materials, 239, 64-69.

[24] Gur-Reznik, S., Koren-Menashe, I., Heller-Grossman, L., Rufel, O. and Dosoretz, C.G. (2011) Influence of Seasonal and Operating Conditions on the Rejection of Pharmaceuticals Active Compounds by RO and NF Membranes. Desalination, 277, 250-256.

[25] Linares, R.V., Yangali-Quintanilla, V., Li, Z. and Amy, G. (2011) Rejection of Micropollutants by Clean and Fouled forward Osmosis Membrane. Water Research, 45, 6737-6744.

[26] Chon, K., Cho, J. and Shon, H.K. (2013) A Pilot-Scale Hybrid Municipal Wastewater Reclamation System Using Combined Coagulation and Disc Filtration, Ultrafiltration and Reverse Osmosis: Removal of Nutrients and Micropollutants, and Characterization of Membrane Foulants. Bioresource Technology, 141, 109-116.

[27] Yangali-Quintanilla, V., Sadmani, A., McConville, M., Kennedy, M. and Amy, G. (2009) Rejection of Pharmaceutically Active Compounds and Endocrine Disrupting Compounds by Clean and Fouled Nanofiltration Membranes. Water Research, 43, 2349-2362.

[28] Garcia, N., Moreno, J., Cartmell, E., Rodriguez-Roda, I. and Judd, S. (2013) The Application of Microfiltration-Reverse Osmosis/Nanofiltration to Trace Organics Removal for Municipal Wastewater Reuse. Environmental Technology, 34, 31833189. https://doi.org/10.1080/09593330.2013.808244

[29] Rodriguez-Mozaz, S., Ricart, M., Köck-Schulmeyer, M., Guasch, H., Bonnineau, C., Proia, L., Alda, M.L., Sabater, S. and Barceló, D. (2015) Pharmaceuticals and Pesticides in Reclaimed Water: Efficient Assessment of a Microfiltration-Reverse Osmosis (MF-RO) Pilot Plant. Journal of Hazardous Materials, 282, 165-173.

[30] Huang, H., Cho, H., Schwab, K. and Jacangelo, J.G. (2011) Effects of Feedwater Pretreatment on the Removal of Organic Microconstituents by a Low Fouling Reverse Osmosis Membrane. Desalination, 281, 446-454.

[31] Lee, C.O., Howe, K.J. and Thomson, B.M. (2012) Ozone and Biofiltration as an Alternative to Reverse Osmosis for Removing PPCPs and Micropollutants from Treated Wastewater. Water Research, 46, 1005-1014.

[32] Sadmani, A.A., Andrews, R.C. and Bagley, D.M. (2014) Influence of Naturally Occurring Dissolved Organic Matter, Colloids and Cations on Nanofiltration of Pharmaceutically Active and Endocrine Disrupting Compounds. Chemosphere, 117, 170-177.

[33] Sanches, S., Galinha, C.F., Crespo, M.T., Pereira, V.J. and Crespo, J.G. (2013) Assessment of Phenomena Underlying the Removal of Micropollutants during Water Treatment by Nanofiltration Using Multivariate Statistical Analysis. Separation and Purification Technology, 118, 377-386.

[34] Sanches, S., Penetra, A., Rodrigues, A., Cardoso, V.V., Ferreira, E., Benoliel, M.J., Barreto Crespo, M.T., Crespo, J.G. and Pereira, V.J. (2013) Removal of Pesticides from Water Combining Low Pressure UV Photolysis with Nanofiltratio. Separation and Purification Technology, 115, 73-82.

[35] Porter, M.C. (1998) Handbook of Industrial Membrane Technology. Noyes Publications. 
[36] Noble, R.D. and Stern, S.A. (1999) Membrane Separations Technology: Principles and Applications. 2nd Edition, Elsevier, Amsterdam.

[37] Li, N.N., Fane, A.G., Winston, W.S. and Matsuura, T. (2008) Advanced Membrane Technology and Applications. John Wiley \& Sons, Inc., Hoboken. https://doi.org/10.1002/9780470276280

[38] Klüpfel, A.M. and Frimmel, F.H. (2010) Nanofiltration of River Water-Fouling, Cleaning and Micropollutant Rejection. Desalination, 250, 1005-1007.

[39] Kaminska, G., Bohdziewicz, J., Calvo, J.I., Prádanos, P., Palacio, L. and Hernandéz, A. (2015) Fabrication and Characterization of Polyethersulfone Nanocomposite Membranes for the Removal of Endocrine Disrupting Micropollutants from Wastewater. Mechanisms and Performance. Membrane Science, 493, 66-79.

[40] Al-Rifai, J.H., Khabbazb, H. and Schäferc, A.I. (2011) Removal of Pharmaceuticals and Endocrine Disrupting Compounds in a Water Recycling Processes Using Reverse Osmosis System. Separation and Purification Technology, 77, 60-67.

[41] Nogueira, R.F.P. and Jardim, W.F. (1998) A fotocatálise heterogênea e sua aplicação ambiental. Química Nova, 21, 69-72.

https://doi.org/10.1590/S0100-40421998000100011

[42] Esplugas, S., Bila, D.M., Krause, L.G.T. and Dezotti, M. (2007) Ozonation and Advanced Oxidation Technologies to Remove Endocrine Disrupting Chemicals (EDCs) and Pharmaceuticals and Personal Care Products (PPCPs) in Water Effluents. Journal of Hazardous Materials, 149, 631-642.

[43] Kommineni, S., Zoeckler, J., Stocking, A., et al. (2000) Chapter 3. Advanced Oxidation Process. In: Treatment Technologies for Removal of Methyl Tertiary Butyl Ether (MTBE) from Drinking Water. Air Stripping, Advanced Oxidation Processes, Granular Activated Carbon and Synthetic Resins Adsorbents, 2nd Edition, National Water Research Institute, Fountain Valley, California, 109-208.

[44] Oxidation Handbook (1994) Solarchem Environmental System. Ontario.

[45] Assalin, M.R. and Durán, N. (2006) Novas tendências para aplicação de ozônio no tratamento de residuos: ozonização catalítica [New Trends for Ozone Application in the Treatment of Waste: Catalytic Ozonation]. Revista Analytica, 26, 76-78.

[46] Mahmoud, A. and Freire, R.S. (2007) Métodos emergentes para aumentar a eficiência do ozônio no tratamento de águas contaminadas [Emerging Methods to Increase the Efficiency of Ozone in Wastewater Treatment]. Química Nova, 30, 198-205. https://doi.org/10.1590/S0100-40422007000100032

[47] Choi, K.J., Kim, S.G., Kim, C.W. and Park, J.K. (2006) Removal Efficiencies of Endocrine Disrupting Chemicals by Coagulation/Flocculation, Ozonation, Powdered/ Granular Activated Carbon Adsorption, and Chlorination. Korean Journal of Chemical Engineering, 23, 399-408. https://doi.org/10.1007/BF02706741

[48] Gerrity, D., Gamage, S., Holady, J.C., Mawhinney, D.B., Quiñones, O., Trenholm, R.A. and Snyder, S.A. (2011) Pilot-Scale Evaluation by Ozone and Biological Activated Carbon for Trace Organic Contaminant Mitigation and Disinfection. Water Research, 45, 2155-2165.

[49] Lee, Y., Kovalova, L., McArdell, C.S. and Gunten, U.S. (2014) Prediction of Micropollutant Elimination during Ozonation of a Hospital Wastewater Effluent. Water Research, 64, 134-148.

[50] Nakada, N., Shinohara, H., Murata, A., Kiri, K., Managaki, S., Sato, N. and Takada, H. (2007) Removal of Selected Pharmaceuticals and Personal Care Products (PPCPs) and Endocrine-Disrupting Chemicals (EDCs) during Sand Filtration and Ozonation at a Municipal Sewage Treatment Plant. Water Research, 41, 4373-4382.

[51] Munter, R. (2001) Advanced Oxidation Processes-Current Status and Prospects. 
Proceedings of the Estonian Academy of Sciences, 50, 59-80.

[52] Pereira, V.J., Galinha, J., Crespo, M.T.B., Matos, C. and Crespo, J. (2012) Integration of Nanofiltration, UV Photolysis, and Advanced Oxidation Processes for the Removal of Hormones from Surface Water Sources. Separation and Purification Technology, 95, 89-96.

[53] Souissi, Y., Bourcier, S., Bouchonnet, S., Genty, C. and Sablier, M. (2012) Estrone Direct Photolysis: By-Product Identification Using LC-Q-TOF. Chemosphere, 87, 185-193.

[54] Carlson, J.C., Stefan, M.I., Parnis, J.M. and Metcalf, C.D. (2015) Direct UV Photolysis of Select Pharmaceuticals, Personal Care Products and Endocrine Disruptors in Aqueous Solution. Water Research, 84, 350-361.

[55] Chen, H., Bramanti, E., Longo, I., Onor, M. and Ferrari, C. (2011) Oxidative Decomposition of Atrazine in Water in the Presence of Hydrogen Peroxide Using an Innovate Microwave Photochemical Reactor. Journal of Hazardous Materials, 186, 1808-1815.

[56] De la Cruz, N., Giménez, J., Esplugas, S., Grandjean, D., Alencastro, L.F. and Pulgarín, C. (2012) Degradation of 32 Emerging Contaminants by UV and Neutral Photo-Fenton in Domestic Wastewater Effluent Previously Treated by Activated Sludge. Water Research, 46, 1947-1957.

[57] Han, O., Wang, H., Dong, W., Liu, T., Yin, Y. and Fan, H. (2015) Degradation of Bisphenol A by Ferrate(VI) Oxidation: Kinetics, Products and Toxicity Assessment. Chemical Engineering Journal, 262, 34-40.

[58] Hernández-Leal, L., Temmink, H., Zeeman, G. and Buisman, C.J.N. (2011) Removal of Micropollutants of Aerobically Treated Grey Water via Ozone and Activated Carbon. Water Research, 45, 2887-2896.

[59] Ibáñez, M., Gracia-Lor, E., Bijlsma, L., Morales, E., Pastor, L. and Hernández, F. (2013) Removal Emerging Contaminants in Sewage Water Subjected to Advanced Oxidation with Ozone. Journal of Hazardous Materials, 260, 389-398.

[60] Kim, I., Yamashita, N. and Tanaka, H. (2009) Performance of UV and UV/ $\mathrm{H}_{2} \mathrm{O}_{2}$ Processes for the Removal of Pharmaceuticals Detected in Secondary Effluent of a Sewage Treatment Plant in Japan. Journal of Hazardous Materials, 166, 1134-1140.

[61] Kusvuran, E. and Yildirim, D. (2013) Degradation of Bisphenol A by Ozonation and Determination of Degradation Intermediates by Gas Chromatograph-Mass Spectrometry and Liquid Chromatograph-Mass Spectrometry. Chemical Engineering Journal, 220, 6-14.

[62] Kwon, M., Kim, S., Yoon, Y., Jung, Y., Hwang, T.M., Lee, J. and Kang, J.W. (2015) Comparative Evaluation of Ibuprofen Removal by $\mathrm{UV} / \mathrm{H}_{2} \mathrm{O}_{2}$ and $\mathrm{UV} / \mathrm{S}_{2} \mathrm{O}_{8}^{2-}$ Processes for Wastewater Treatment. Chemical Engineering Journal, 269, 379-390.

[63] Laat, J., Gallard, H., Ancelin, S. and Legube, B. (1999) Comparative Study of the Oxidation of Atrazine and Acetone by $\mathrm{H}_{2} \mathrm{O}_{2} / \mathrm{UV}, \mathrm{Fe}(\mathrm{III}) / \mathrm{UV}, \mathrm{Fe}(\mathrm{III}) / \mathrm{H}_{2} \mathrm{O}_{2} / \mathrm{UV}$ and $\mathrm{Fe}(\mathrm{II})$ or $\mathrm{Fe}(\mathrm{III}) / \mathrm{H}_{2} \mathrm{O}_{2}$. Chemosphere, 39, 2693-2706.93.

[64] Ning, B., Graham, N.J.D. and Zhang, Y. (2007) Degradation of Octylphenol and Nonylphenol by Ozone-Part II: Indirect Reaction. Chemosphere, 68, 1173-1179.

[65] Oh, B.S., Jung, Y.J., Oh, Y.J., Yoo, Y.S. and Kang, J.W. (2006) Application of Ozone, UV and Ozone/UV Processes to Reduce Diethyl Phthalate and Its Estrogenic Activity. Science of the Total Environment, 367, 681-693.

[66] Olmez-Hanci, T., Dursun, D., Aydin, E., Arslan-Alaton, I., Girit, B., Mita, L., Diano, N., Mita, D.G. and Guida, M. (2015) $\mathrm{S}_{2} \mathrm{O}_{8}^{2-} / \mathrm{UV}-\mathrm{C}$ and $\mathrm{H}_{2} \mathrm{O}_{2} / \mathrm{UV}-\mathrm{C}$ Treatment of Bisphenol-A: Assessment of Toxicity, Estrogenic Activity, Degradation Products 
and Results in Real Water. Chemosphere, 119, S115-S123.

[67] Richard, J., Boergers, A., Eyser, C.V., Bester, K. and Tuerk, J. (2014) Toxicity of the Micropollutants Bisphenol A, Ciprofloxacin, Metoprolol and Sulfamethoxazole in Water Samples before and after the Oxidative Treatment. International Journal of Hygiene and Environmental Health, 217, 506-514.

[68] Suri, R.P.S., Singh, T.S. and Abburi, S. (2010) Influence of Alkalinity and Salinity on the Sonochemical Degradation of Estrogen Hormones in Aqueous Solution. Environmental Science \& Technology, 44, 1373-1379. https://doi.org/10.1021/es9024595

[69] Sarkar, S., Ali, S., Rehmann, L., Nakhla, G. and Ray, M.B. (2014) Degradation of Estrone in Water and Wastewater by Various Advanced Oxidation Processes. Journal of Hazardous Materials, 278, 16-24.

[70] Aguinaco, A., Beltrán, F.J., García-Araya, J.F. and Oropesa, A. (2012) Photocatalytic Ozonation to Removal Pharmaceutical Diclofenac from Water: Influence of Variables. Chemical Engineering Journal, 189, 275-282.

[71] Balci, B., Oturan, N., Cherrier, R. and Oturan, M.A. (2009) Degradation of Atrazine in Aqueous Medium by Electrocatalytically Generated Hydroxyl Radicals. A Kinetic and Mechanistic Study. Water Research, 43, 1924-1934.

[72] Khan, J.A., He, X., Shah, N.S., Khan, H.M., Hapeshi, E., Fatta-Kassinos, D. and Dionysiou, D.D. (2014) Kinetic and Mechanism Investigation on the Photochemical Degradation of Atrazine with Activated $\mathrm{H}_{2} \mathrm{O}_{2}, \mathrm{~S}_{2} \mathrm{O}_{8}^{2-}$ and $\mathrm{HSO}_{5}^{-}$. Chemical Engineering Journal, 252, 393-403.

[73] Silva, L.S.S., Sales, J.C.S., Campos, J.C., Bila, D.M. and Fonseca, F.V. (2016) Advanced Oxidative Processes and Membrane Separation for Micropollutant Removal from Biotreated Domestic Wastewater. Environmental Science and Pollution Research, 24, 6329-6338.

[74] Gebhardt, W. and Schröder, H.F. (2007) Liquid Chromatography-(Tandem) Mass Spectrometry for the Follow-Up of the Elimination of Persistent Pharmaceuticals during Wastewater Treatment Applying Biological Wastewater Treatment and Advanced Oxidation. Journal of Chromatograph A, 1160, 34-43.

[75] Miralles-Cuevas, S., Arqués, A., Maldonado, M.I., Sánchez-Pérez, J.A. and Rodríguez, S.M. (2013) Combined Nanofiltration and Photo-Fenton Treatment of Water Containing Micropollutants. Chemical Engineering Journal, 224, 89-95.

[76] James, C.P., Germain, E. and Judd, S. (2014) Micropollutant Removal by Advanced Oxidation of Microfiltered Secondary Effluent for Water Reuse. Separation and Purification Technology, 127, 77-83.

[77] Löwenberg, J., Zenker, A., Baggenstos, M., Koch, G., Kazner, C. and Wintgens, T. (2014) Comparison of Two PAC/UF Processes for the Removal of Micropollutants from Wastewater Treatment Plant Effluent: Process Performance and Removal Efficiency. Water Research, 56, 26-36.

[78] Arzate, S., Sánches, J.L.G., Soriano-Molina, P., Lópes, J.L.C., Campos-Mañas, M.C., Agüera, A. and Péres, J.A.S. (2017) Effect of Residence Time on Micropollutant Removal in WWTP Secondary Effluents by Continuous Solar Photo-Fenton Process in Raceway Pond Reactors. Chemical Engineering Journal, 316, 1114-1121.

[79] Lau, T.K., Chu, W. and Graham, N. (2005) The Degradation of Endocrine Disruptor di-n-butilphthalate by UV Irradiation: A Photolysis and Product Study. Chemosphere, 60, 1045-1053.

[80] Zhang, Z., Feng, Y., Liu, Y., Sun, Q., Gao, P. and Ren, N. (2010) Kinetic Degradation model and Estrogenicity Changes of EE2 (17 $\alpha$-Ethinylestradiol) in Aqueous Solution by UV and $\mathrm{UV} / \mathrm{H}_{2} \mathrm{O}_{2}$ Technology. Journal of Hazard Materials, 181, 1127- 
1133.

[81] Shu, Z., Bolton, J.R., Belosevic, M. and ElGin, M.G. (2013) Photodegradation of Emerging Micropollutants Using the Medium-Pressure $\mathrm{UV} / \mathrm{H}_{2} \mathrm{O}_{2}$ Advanced Oxidation Process. Water Research, 47, 2881-2889.

[82] Yan, C., Nie, M., Yang, Y., Zhou, J., Liu, M., Baalousha, M. and Lead, J.R. (2015) Effect of Colloids on the Occurrence, Distribution and Photolysis of Emerging Organic Contaminants in Wastewaters. Journal of Hazardous Materials, 299, 241-248.

[83] Shanmuganathan, S., Loganathan, P., Kazner, C., Johir, M.A.H. and Vigneswaran, S. (2017) Submerged Membrane Filtration Adsorption Hybrid System for the Removal of Organic Micropollutants from a Water Reclamation Plant Reverse Osmosis Concentrate. Desalination, 401, 134-141.

[84] Park, M., Anumol, T., Simon, J., Zraick, F. and Snyder, S.A. (2017) Pre-Ozonation for High Recovery of Nanofiltration (NF) Membrane System: Membrane Fouling Reduction and Trace Organic Compound Attenuation. Journal of Membrane Science, 523, 255-263.

[85] Schaar, H., Clara, M., Gans, O. and Kreuzinger, N. (2010) Micropollutant Removal during Biological Wastewater Treatment and a Subsequent Ozonation Step. Environmental Pollution, 158, 1399-1404.

[86] Laoufi, N.A., Hout, S., Tassalit, D., Ounar, A., Djouadi, A., Chekir, N. and Bentahar, F. (2013) Removal of a Persistent Pharmaceutical Micropollutant by $\mathrm{UV} / \mathrm{TiO}_{2}$ Process Using an Immobilized Titanium Dioxide Catalyst: Parametric Study. Chemical Engineering Transactions, 32, 1951-1956.

[87] Plakas, K.V., Sarasidis, V.C., Patsios, S.I., Lambropoulou, D.A. and Karabelas, A.J. (2016) Novel Pilot Scale Continuous Photocatalytic Membrane Reactor for Removal of Organic Micropollutants from Water. Chemical Engineering Journal, 304, 335343.

[88] Ahmed, M.M., Brienza, M., Goetz, V. and Chiron, S. (2014) Solar Photo-Fenton Using Peroxymonosulfate for Organic Micropollutants Removal from Domestic Wastewater: Comparison with Heterogeneous $\mathrm{TiO}_{2}$ Photocatalysis. Chemosphere, 117, 256-261.

Scientific Research Publishing

Submit or recommend next manuscript to SCIRP and we will provide best service for you:

Accepting pre-submission inquiries through Email, Facebook, LinkedIn, Twitter, etc. A wide selection of journals (inclusive of 9 subjects, more than 200 journals)

Providing 24-hour high-quality service

User-friendly online submission system

Fair and swift peer-review system

Efficient typesetting and proofreading procedure

Display of the result of downloads and visits, as well as the number of cited articles

Maximum dissemination of your research work

Submit your manuscript at: http://papersubmission.scirp.org/

Or contact jwarp@scirp.org 